\title{
RESULTS OF THE 2006 INTERNATIONAL BUTTERFLY COUNTS IN SASKATCHEWAN
}

MIKE GOLLOP, 51 Welker Crescent, Saskatoon, SK S7H 3M3 and ANNA LEIGHTON, 328 Saskatchewan Crescent West, Saskatoon, SK S7M OA4

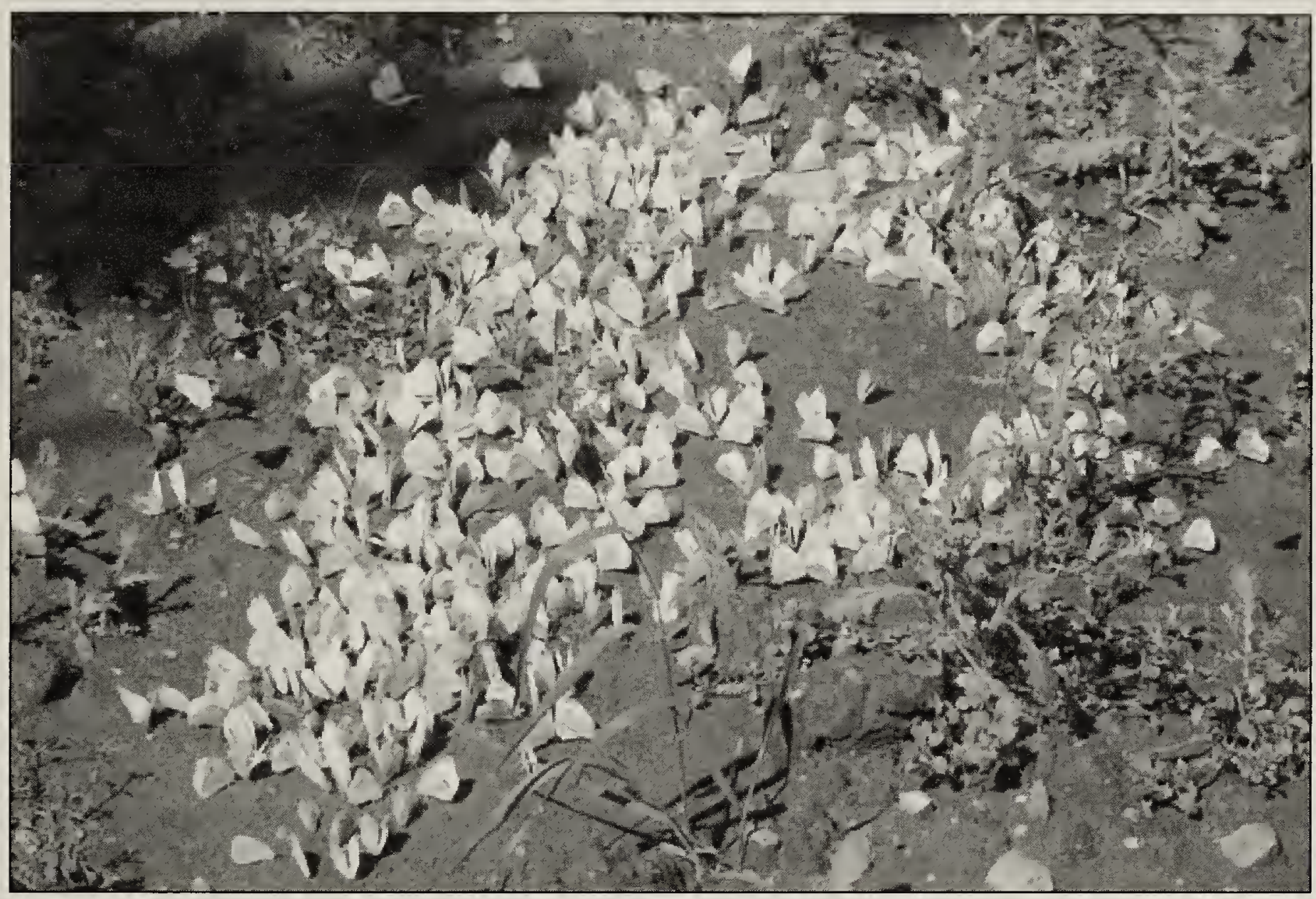

Figure 1. Cabbage White butterflies mudpuddling near Bjorkdale, 14 August 2006.

John Kozial

Eight international butterfly counts, also called First of July Counts or $1 \mathrm{JC}$, were held in Saskatchewan in 2006. This was the same number as in 2005 , although only five of these counts were held in both years. ${ }^{1}$ Counts in 2006 were conducted at Bjorkdale, Eastend, Fort Qu'Appelle, Pasquia Hills, Preeceville, Regina, Saskatoon and Waskesiu River. The Eastend, Bjorkdale and Pasquia Hills counts were not done in 2005.

In 2006, 62 species were recorded, compared to 57 in 2005. ${ }^{1}$ The total number of butterflies counted in 2006 was 3669 compared to 6972 in 2005 (of which 5389 were Painted Ladies). Butterflies per party hour in 2006 was 48 compared to 86 in 2005 , although if Painted Ladies were removed from the 2005 count, the butterflies per partyhour would have been only 27 . (The number of butterflies counted per partyhour is a measure that relates butterfly numbers to observer effort, to provide a comparable index of abundance over years.)

Count conditions were consistent 
Table 1. 1JC statistics - Saskatchewan 2006

\begin{tabular}{|l|l|l|l|l|l|l|l|l|l|c|c|c|c|}
\hline $\begin{array}{l}\text { 1JC } \\
\text { name }\end{array}$ & $\begin{array}{l}\text { 1.JC } \\
\text { date }\end{array}$ & $\begin{array}{l}\text { no. of } \\
\text { spp. }\end{array}$ & $\begin{array}{l}\text { no. of } \\
\text { b'flies }\end{array}$ & $\begin{array}{l}\text { b'flies/ } \\
\text { ph }\end{array}$ & $\begin{array}{l}\text { no. of } \\
\text { obs. }\end{array}$ & $\begin{array}{l}\text { no. of } \\
\text { ph }\end{array}$ & $\begin{array}{l}\text { ph on } \\
\text { foot }\end{array}$ & $\begin{array}{l}\mathrm{km} \text { on } \\
\text { foot }\end{array}$ & $\begin{array}{l}\mathrm{km} \text { by } \\
\text { car }\end{array}$ & time & $\begin{array}{l}\% \text { sun } \\
\text { am:pm }\end{array}$ & $\begin{array}{l}\text { temp. } \\
\text { deg.C }\end{array}$ & $\begin{array}{l}\text { wind } \\
\mathrm{km} / \mathrm{hr}\end{array}$ \\
\hline WaR & Jun 4 & 15 & 175 & 21 & 2 & 8.2 & 8.2 & 8.6 & 0 & $0930-1615$ & $20: 75$ & 21 & light \\
\hline Reg & Jun 22 & 18 & 350 & 28 & 6 & 12.5 & 9.5 & 13 & 3 & $0900-1500$ & $100: 85$ & $18-22$ & $3-15$ \\
\hline FtQ & Jun 24 & 25 & 115 & 19 & 4 & 6 & 5 & 8 & 45 & $1030-1600$ & $100: 50$ & 23 & 8 \\
\hline Bjo & Jul 3 & 21 & 455 & 57 & 1 & 8 & 4 & 5 & 35 & $0900-1700$ & $100: 80$ & $19-22$ & $10-20$ \\
\hline PaH & Jul 6 & 23 & 374 & 47 & 1 & 8 & 1 & 2 & 20 & $0900-1700$ & $100: 100$ & $22-31$ & $5-15$ \\
\hline Sto & Jul 8 & 28 & 429 & 21 & 11 & 20 & 24 & 11.2 & 45 & $0900-1700$ & $90: 90$ & $19-24$ & $22-35$ \\
\hline Pre & Jul 22 & 16 & 619 & 88 & 6 & 7 & 4 & 6 & 20 & $0830-1530$ & $90: 75$ & $20-32$ & $0-40$ \\
\hline Eas & Aug 10 & 13 & 1152 & 164 & 2 & 7 & 7 & 23 & 0 & $0930-1510$ & $100: 100$ & $20-26$ & 10 \\
\hline totals & 8 IJCs & 62 & 3669 & 48 & 27 & 77 & 63 & 77 & 169 & & & $18-32^{*}$ & $0-40^{*}$ \\
\hline
\end{tabular}

Abbreviations: WaR = Waskesiu River, Reg = Regina, FtQ = Fort Qu'Appelle, Bjo = Bjorkdale, PaH = Pasquia Hills, Sto $=$ Saskatoon, Pre $=$ Preeceville, Eas $=$ Eastend, $s p p .=$ species, ${ }^{*}$ extremes for the year, ph $=$ party hours.

among counts in 2006, with temperatures ranging from a low of $18^{\circ} \mathrm{C}$ at Regina to a high of $32^{\circ} \mathrm{C}$ at Preeceville (Table 1). Wind speeds increased to 35 and $40 \mathrm{~km} / \mathrm{hr}$ on the Saskatoon and Preeceville counts, respectively, and may have influenced the number of open field butterflies seen on those counts. The number of observers was about the same in both years, and in 2006 ranged from one on the Bjorkdale and Pasquia Hills counts to 11 at Saskatoon. A total of 77 partyhours were logged, ranging from six at Fort Qu'Appelle to 20 at Saskatoon.

Species totals on the eight counts ranged from 13 at Eastend to 28 at Regina, and averaged 20 per count for the eight counts. This was up from an average of 18 per count in 2005. Species counts remained down from earlier years, despite the second year of moisture for most of the prairies and in an outstanding flower bloom in many areas. Too much moisture in the northeast of the province, however, reduced numbers on the Bjorkdale and Pasquia Hills counts. In contrast, the southwest had very dry conditions for much of the season, and at Eastend, only 13 species were found, 12 species fewer than the lowest number found in the six previous comparable counts.

Numbers of individual butterflies per count ranged from 115 at Fort Qu'Appelle to 1152 at Eastend.
Cabbage Whites accounted for 837 of the Eastend total (Table 2). As was the case for Painted Ladies in 2005, the high number of Cabbage Whites in 2006 demonstrates how a single species can inflate figures. (See Figure 1.) The number of individual butterflies per party-hour ranged from 19 at Fort Qu'Appelle to 164 at Eastend.

The species with the highest number of individuals seen were Cabbage White at 1502, and Clouded Sulphur at 449. The number of Cabbage Whites was exceptionally high for Saskatchewan 1JCs. In counts held in the past 10 years, numbers of individuals of this species averaged 336 per year; the highest previous total was 456, recorded in 2003. ${ }^{2,3}$ Cabbage Whites appeared in unusually high numbers early in the season in 2006 , at least in south-central parts of the province, as indicated by observations in the Allan Hills by the second author: seven Cabbage Whites on May 7 , and nine on May 14. Good conditions for survival and reproduction must have existed in many parts of the province in 2006, as indicated by the build up of numbers seen in the $1 \mathrm{JCs}$ (Table 2).

Although Clouded Sulphur numbers (449) were high compared to 2005 numbers (65), they were lower than the 10 -year average of 563 . Only two years in the past 10 have had lower numbers: 2000 with 295 and 2001 with 339 . The 
Table 2. 1JC results - Saskatchewan 2006

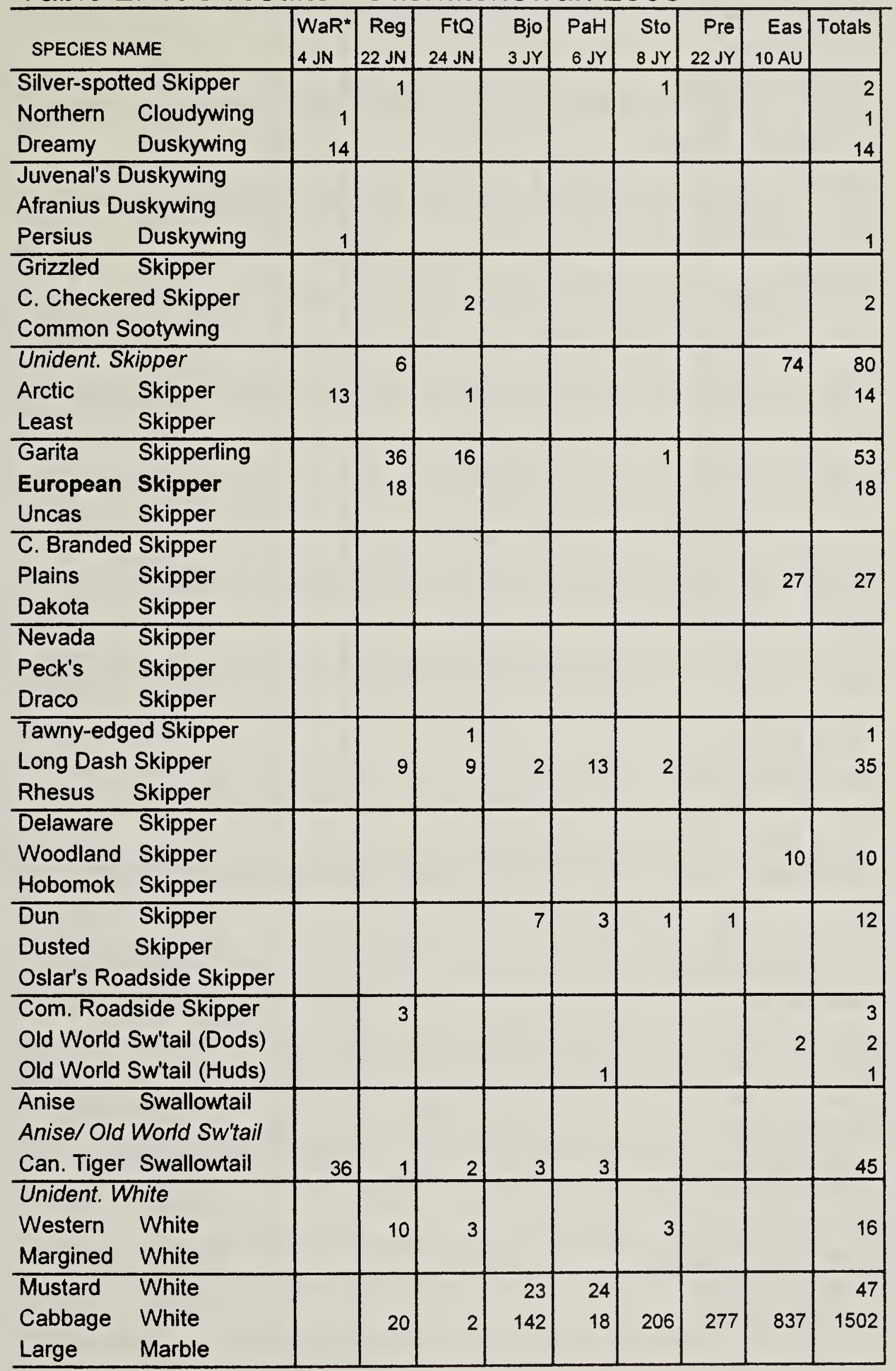




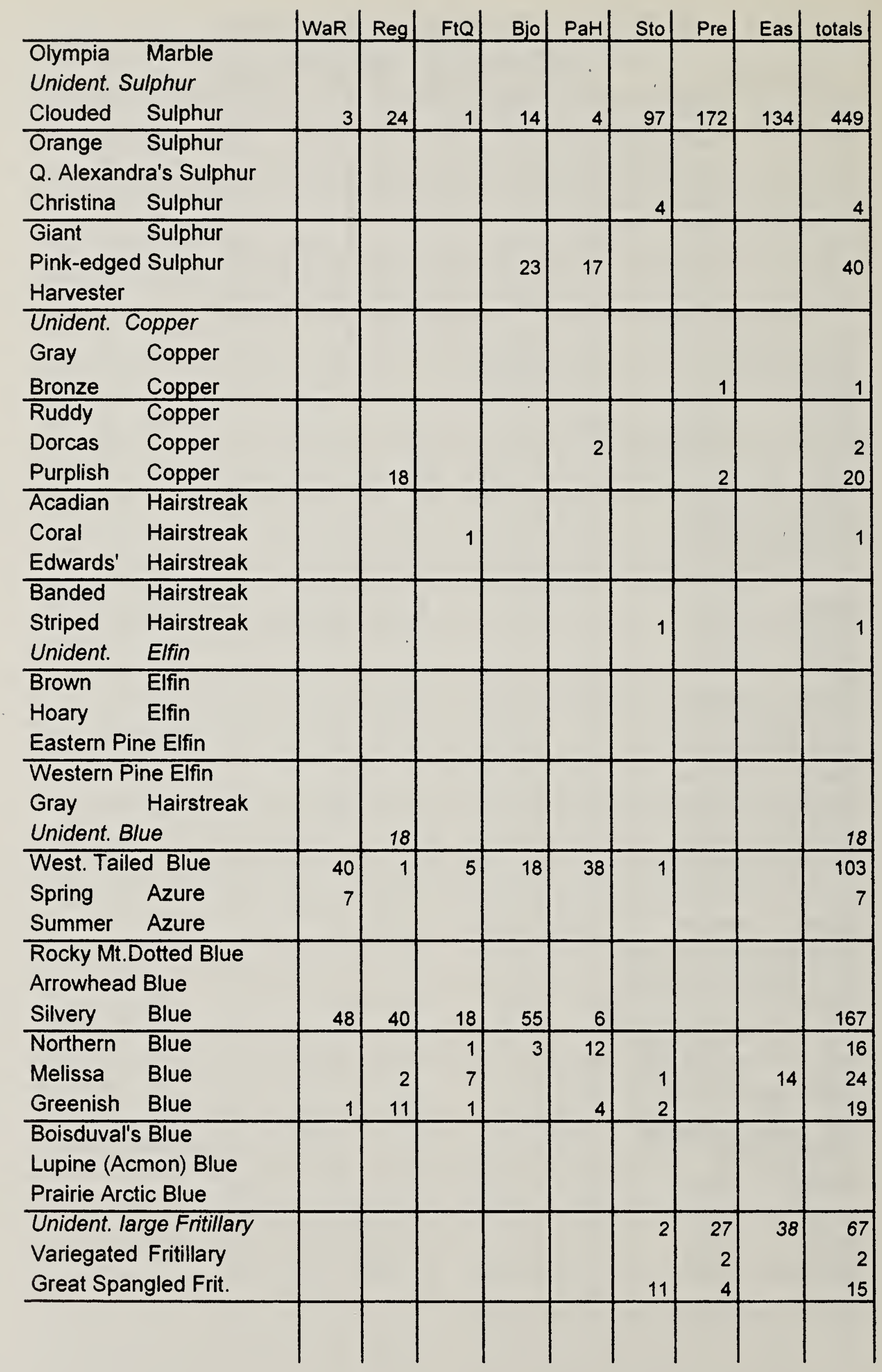




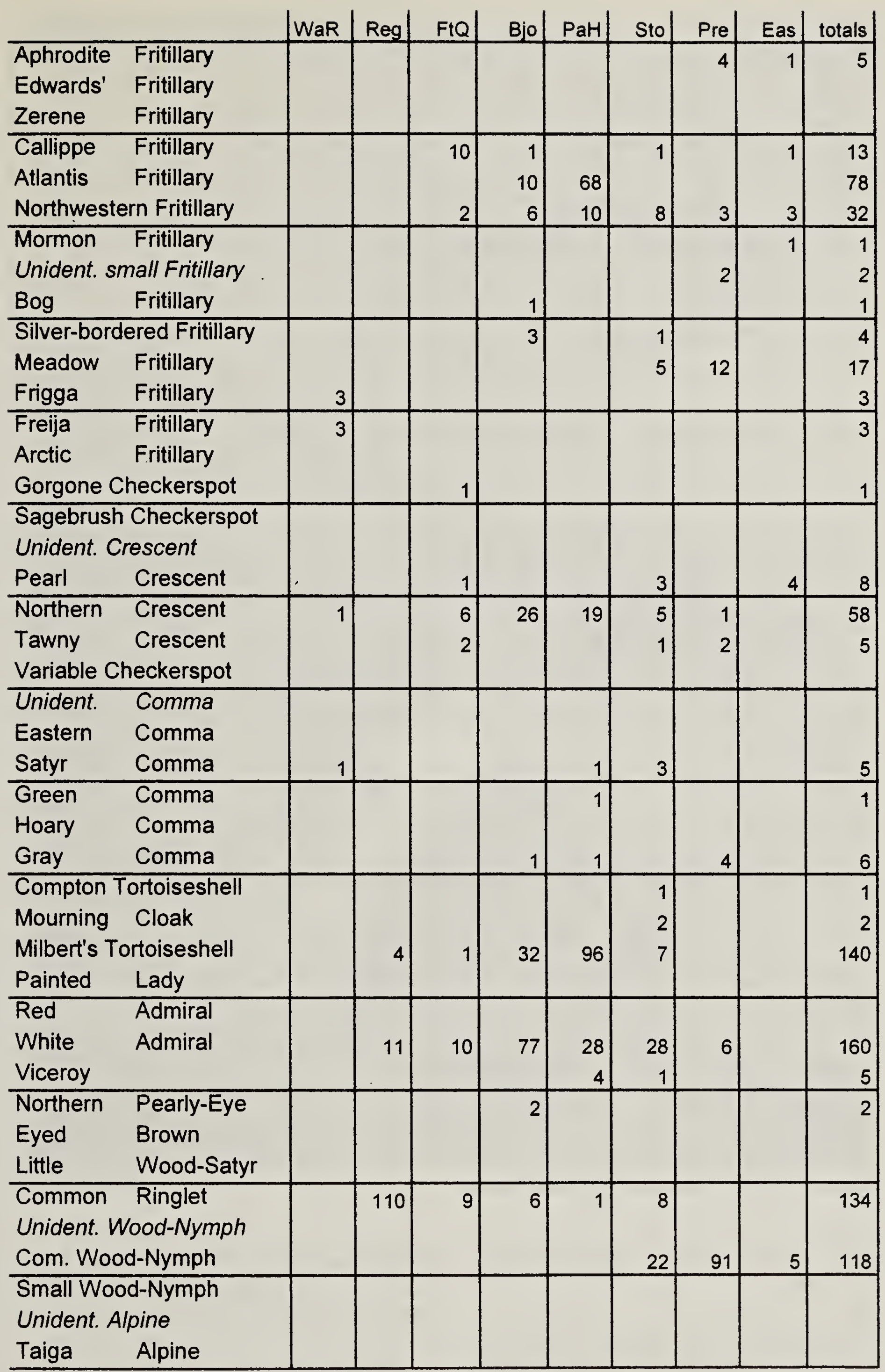




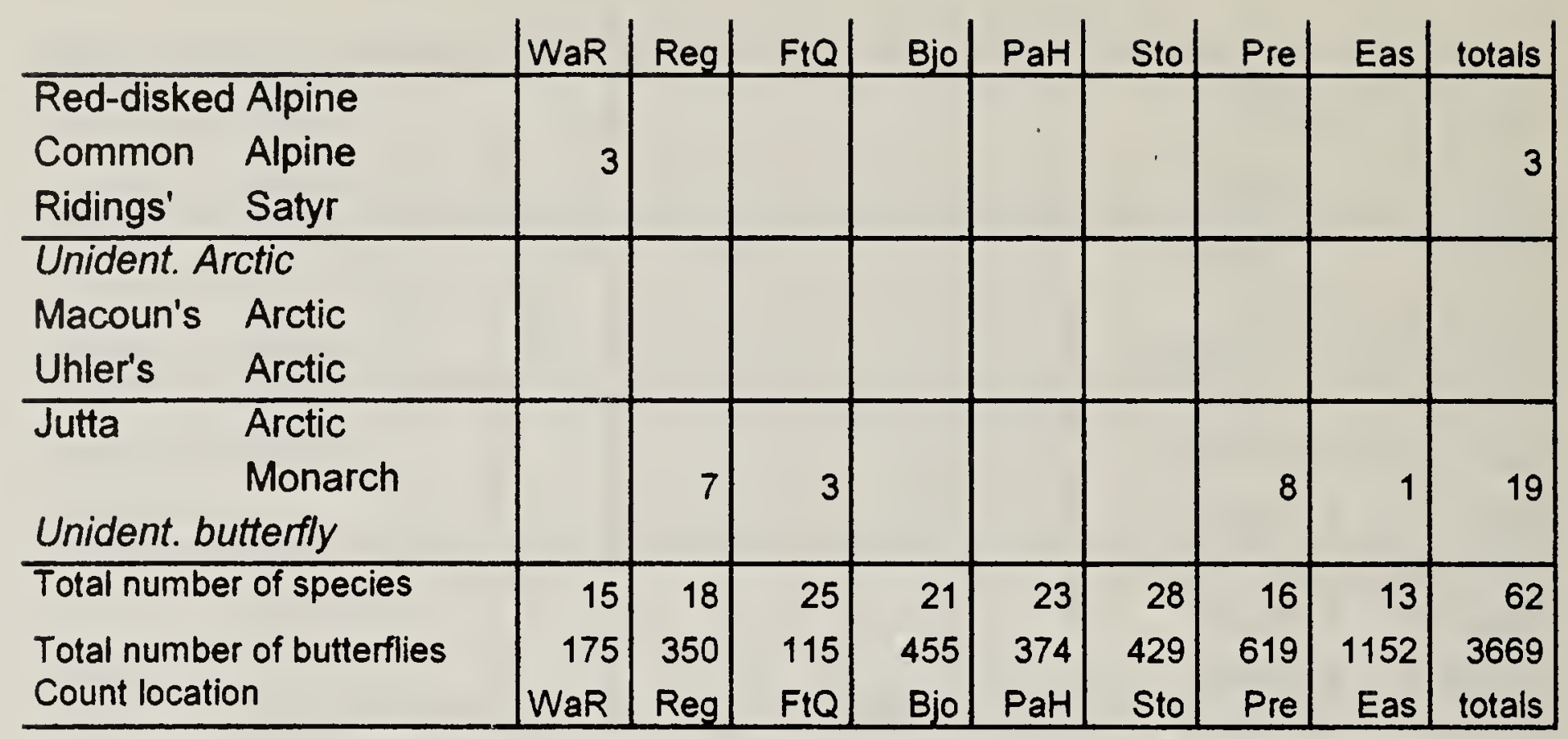

${ }^{*} \mathrm{WaR}=$ Waskesiu River, Reg $=$ Regina, FtQ $=$ Fort Qu'Appelle, Bjo $=$ Bjorkdale, $\mathrm{PaH}=$ Pasquia Hills, Sto $=$ Saskatoon, Pre $=$ Preeceville, Eas $=$ Eastend.

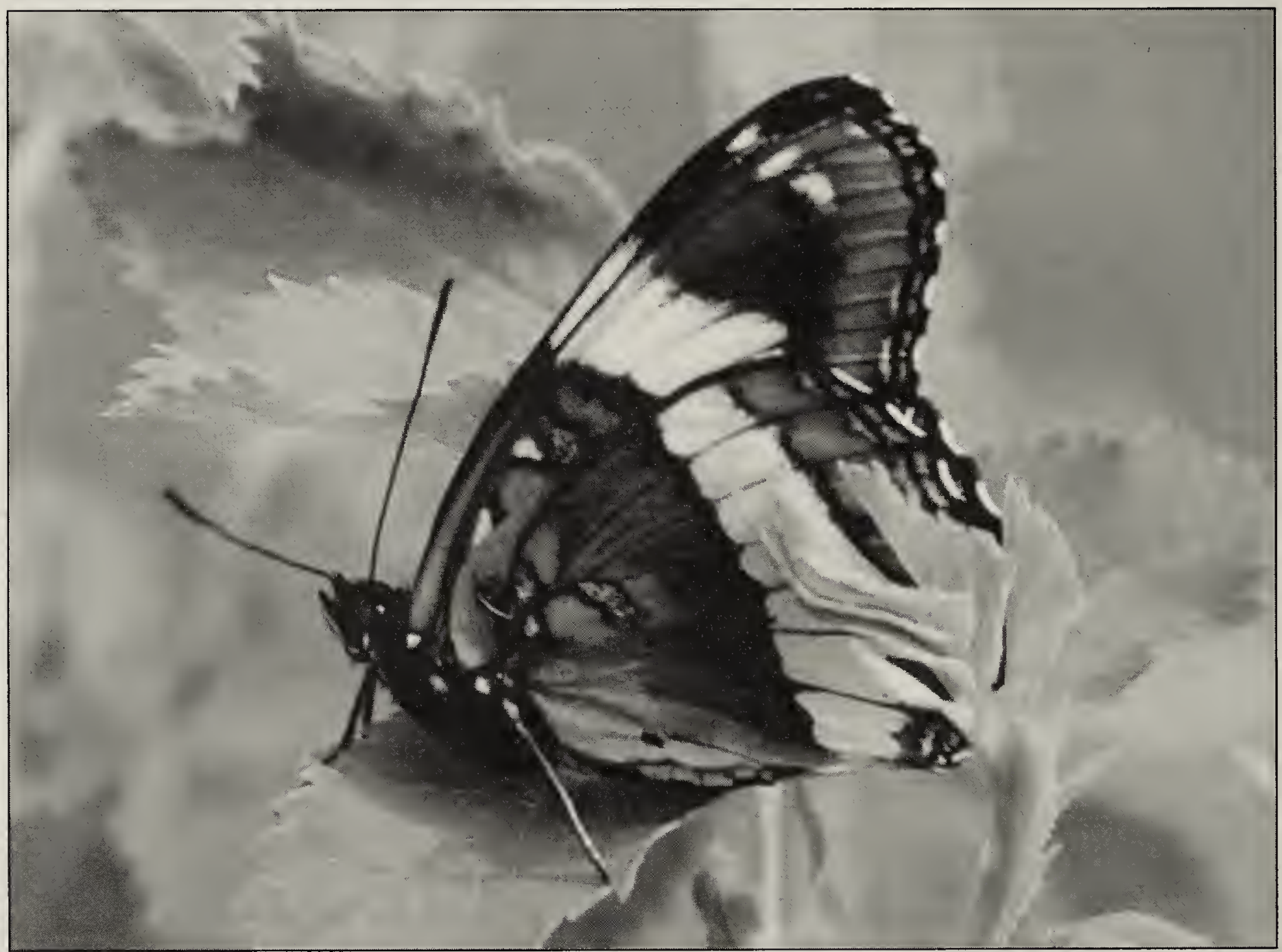

Figure 2. White Admiral, Nisbet Forest, 14 June 2006

Juhachi Asai

highest were 1140 (in 2003) and 957 (in 1999). ${ }^{2,3}$

Unusually high species counts at individual locations included 23 Pinkedged Sulphurs and 77 White Admirals (Figure 2) at Bjorkdale, 12 Northern
Blues, 68 Atlantis Fritillaries and 96 Milbert's Tortoiseshells at Pasquia Hills and 8 Monarchs at Preeceville.

Virtually all of the common species that might be expected, considering the dates and locations of the eight counts, 


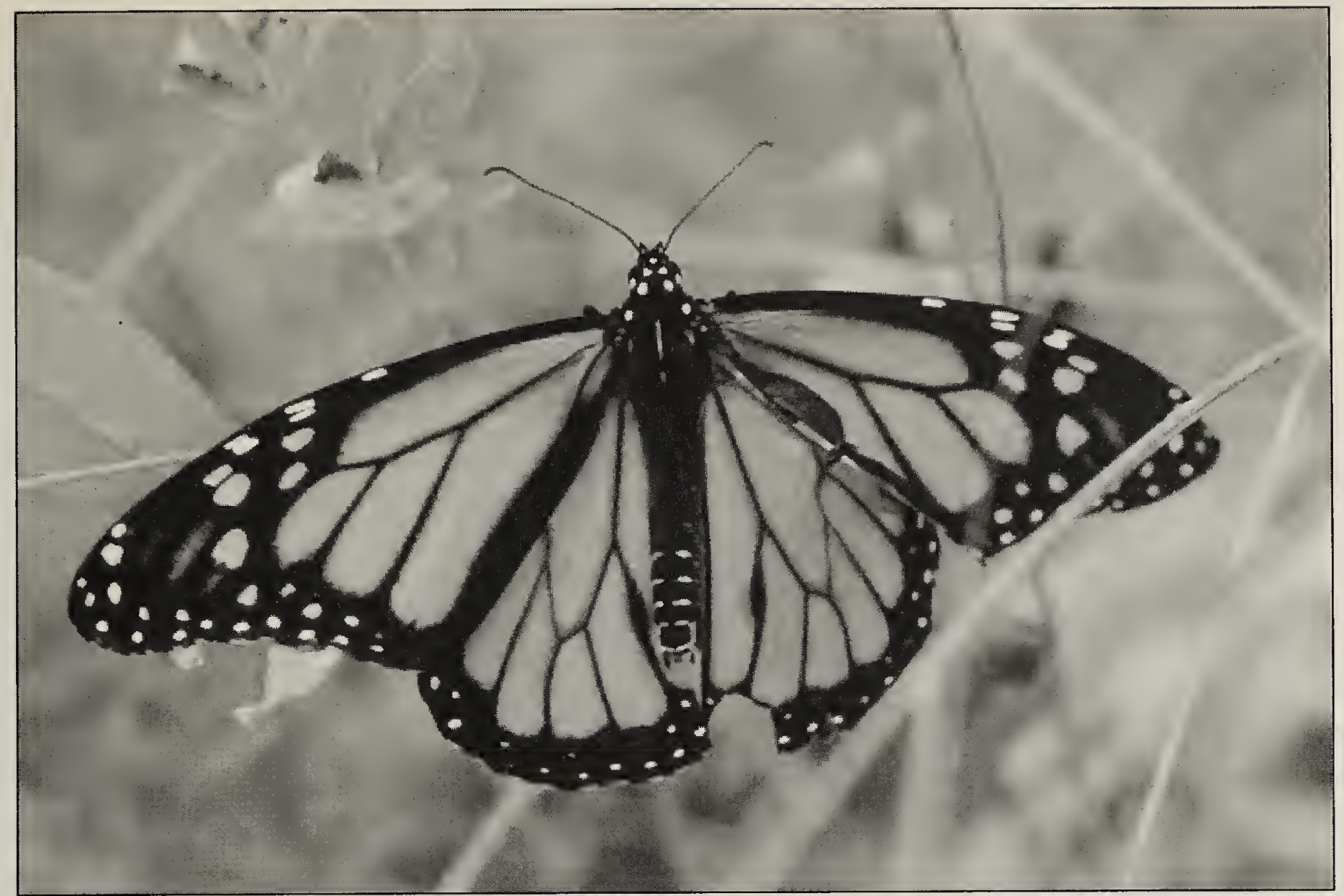

Figure 3. Monarch with damaged wing, Nisbet Forest, 10 August 2006

Juhachi Asai

were found in 2006. Painted Ladies, the species that dominated counts in 2005 and accounted for $77 \%$ of all butterflies seen, were absent from the 2006 counts. Red Admirals, another species that routinely fluctuates dramatically in numbers, also were not seen this year.

The only provincially rare species counted in 2006 was European Skipper: 18 were seen at Regina, where they have recently become established and apparently are increasing. Northern Blues, an unusual butterfly on $1 \mathrm{JCs}$, were reported from three counts, including Fort Qu'Appelle (see photograph on back cover).

The Nisbet Forest count, usually held at the end of July or early August, was initiated on August 10 this year but was canceled due to heavy cloud cover and rain in the morning. On the first leg of the survey, however, a Monarch was found on the ground in a patch of Low Milkweed (Asclepias ovalifolia) in the forest. This individual was unable to fly, due to a malformed front wing, so it was assumed to have emerged at the site (Figure 3 ). In early afternoon, when the sun began to shine, four additional Monarchs were seen at the milkweed patch. All were in fresh condition and, after sitting briefly on the spruce trees at the site, flew away. No chrysalids were located but it appeared that these individuals had emerged earlier that day. A sixth Monarch was found that morning lying dead on a path.

1, GOLLOP, M. and A. LEIGHTON. 2005. Results of the 2005 International Butterfly Count in Saskatchewan. Blue Jay 63:193-199

2. LEIGHTON, A. 2000-2003. Saskatchewan Butterflies 2000, 2001, 2002, 2003. Annual reports published privately.

3. LEIGHTON, A. and B. GOLLOP, 1998-1999. Saskatchewan Butterflies 1998, 1999. Annual reports published privately. 


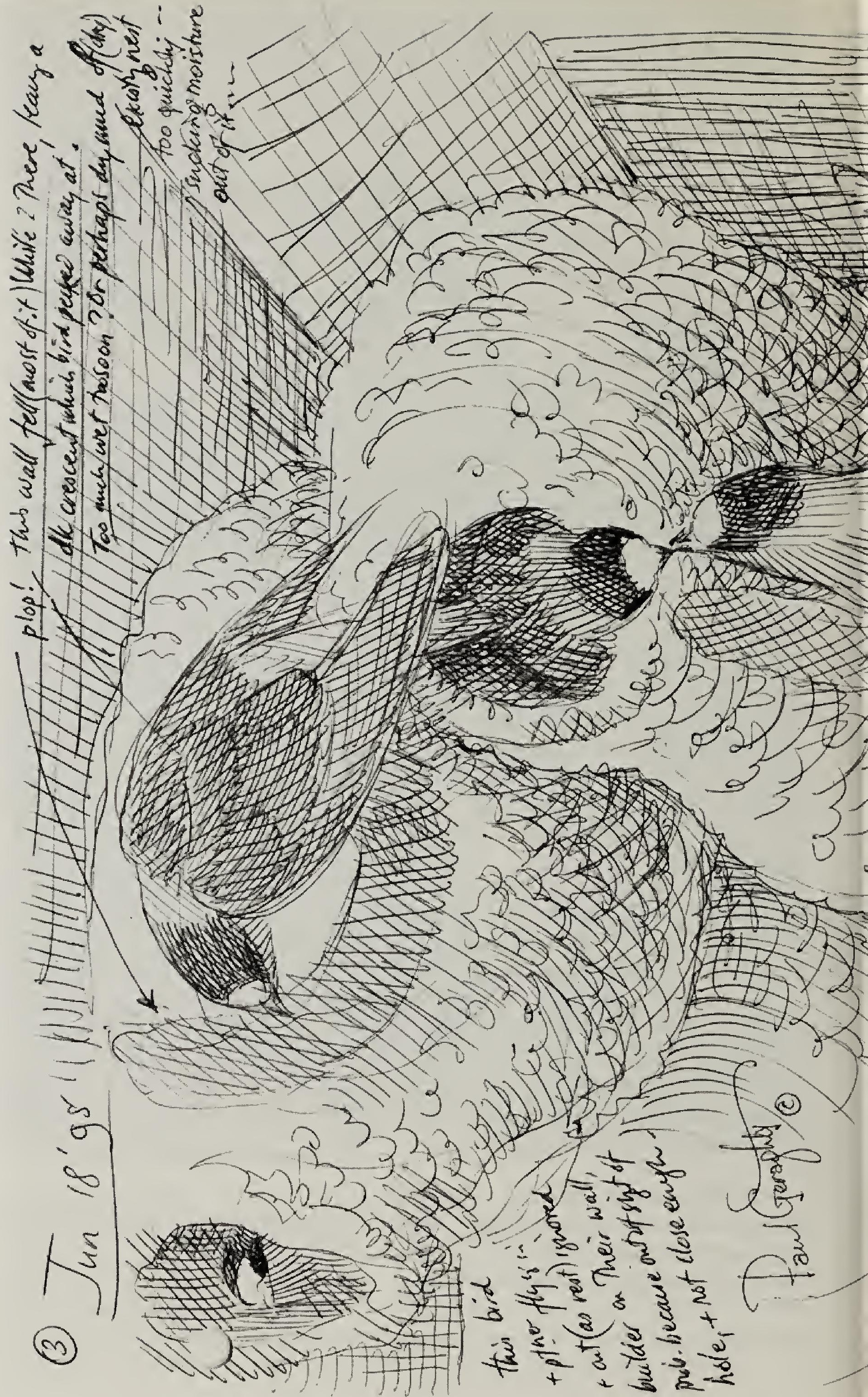




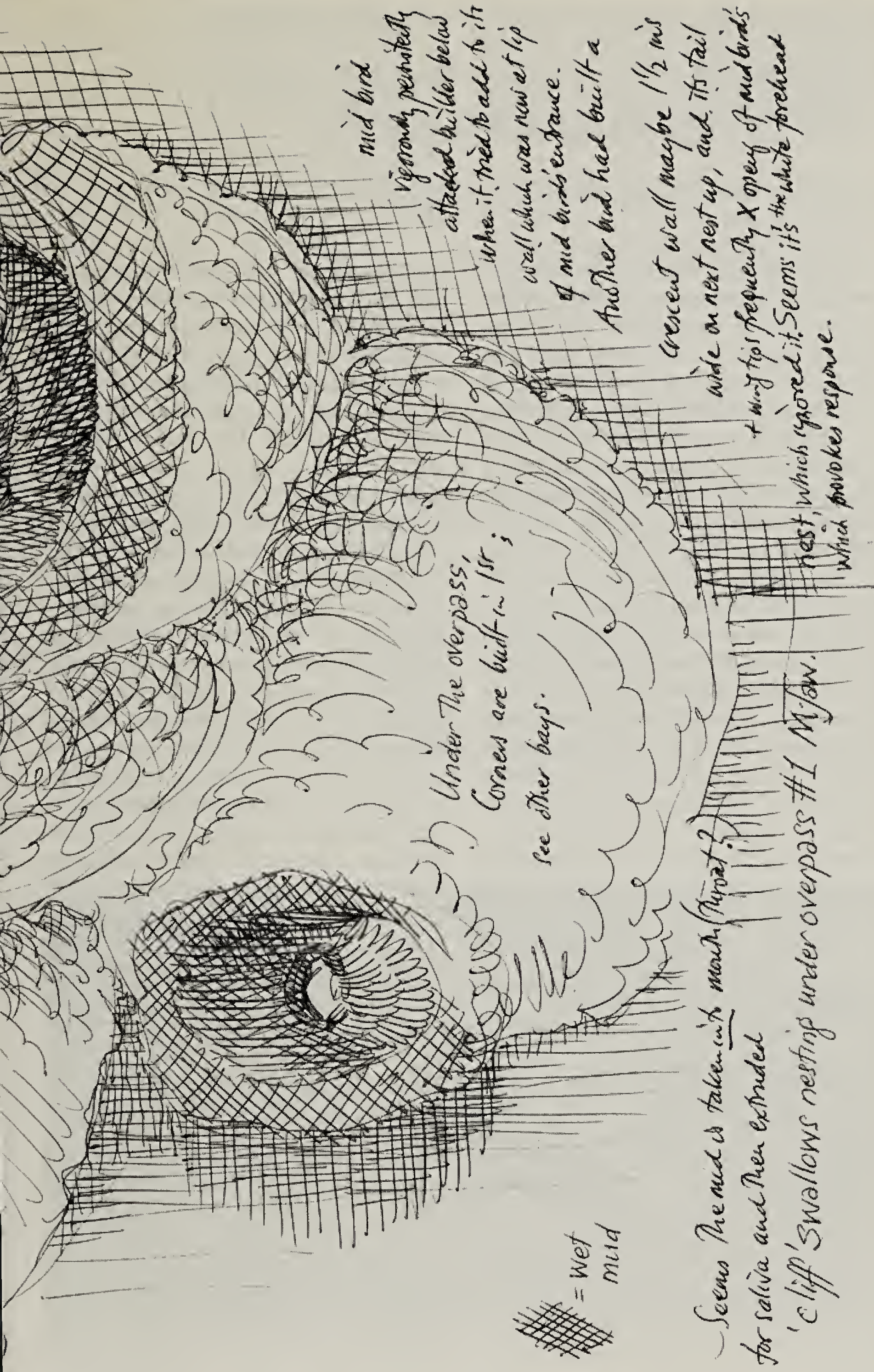

